\title{
Corporate Ijārah Financing: A Case of an Islamic Commercial Bank
}

\author{
Umar Saeed $^{1 *}$, Asad Gul ${ }^{2}$, Waqar Hussain ${ }^{3}$ \\ 1, 2, 3 Mufti, Centre for Excellence in Islamic Finance, Institute of Management Sciences, Peshawar, Pakistan
}

\section{Keywords \\ Ijārah \\ Corporate Client \\ Risks in Ijārah \\ Bank Islami \\ Rental in Ijārah}

\begin{abstract}
The Islamic banking industry facilitates both consumer and corporate clients by providing needed capital through different modes of financing. The pre-requisites of financing the corporate clients are generally different from that of the individual customers. This study discusses a detailed narrative of how a corporate customer, Sufi oil, availed financing from Bank Islami through ijārah mode of financing in a Shari'ah compliant way. It discusses step by step procedure of dealing with corporate client starting from the first stage when a representative of the firm visited the Bank Islami and discussed the firm needs and the possible procedure and mode of financing. The study provide a comprehensive insight in the internal procedures involved in evaluating each and every client. Different branches and their respective role and responsibilities at the branch level and their interaction with the Head Office have been highlighted. The study has also briefly discussed various risks that may encounter the transaction and the manner in which the perceived risks have been mitigated.

The focus of the study is to differentiate the corporate ijärah from the consumer ijärah in terms of both documentation and procedure. The repayment schedule for the case is also described in detail along with the rent that the Bank Islami would be getting by leasing any vehicle to the corporate entity.
\end{abstract}

KAUJIE Classification: J0, K5

JEL Classification: G2

(C) 2018 JIBM. All rights reserved.

\section{INTRODUCTION}

Ijärah is an Islamic mode of financing and usually refers to a leasing contract of property or usable assets, such as land, plant ,office automation, motor vehicle etc., which are leased to a client for a steam of rental and purchase payment, ending with a transfer of ownership to the lessee by way of sale or gift. Broadly, it may be consumer ijārah or corporate ijārah. Corporate Ijärah involves fulfillment of comprehensive procedural and documentation formalities than the consumer ijārah financing. The latter, for example, may only require CNIC copy,

\footnotetext{
${ }^{*}$ Corresponding author: Umar Saeed

†Email: saeedorakzai88@gmail.com
} 
proof of Income other than salary, utility bills, salary slip or pension book in case of retired person, from, the client. But corporate ijārah requires evidence about the principal and subsidiary places of operation of the business, financial worth, value of total assets, business turn over administrative hierarchy as required by SECP, departmentalization, Business, credit history, receipt and payment returns and so on.

\section{The Customer's Need of Ijärah}

This case study highlights the ijärah transaction concluded between Peshawar Based Sufi Oil and Bank Islami. Sufi Oil was established at Hayatabad almost a decade ago. After successful operation in the local market, the firm fell obliged to explore international market. In view of its geographic proximity and similarity of social indicators index, Afghanistan was considered as a good beginning point as a market for its products.

A careful internal estimate revealed that hired transport to Afghanistan would be too costly and inefficient and may nip the initiative in the bud. The financial depth of the firm, on the other hand, could not allow for its owned transport. Recent history of leasing vehicles from Banks for management encouraged the firm to approach Bank Islami for provision of the required facility. The firm approached its Shari' 'ah Consultant and prepared a case for leasing the transport vehicle as per guidelines recommended by him.

\section{Interaction with the Bank}

The Chief Accountant, duely authorized by the firm, visited the Bank Islami for initial ascertainment of the ijärah. After initial inquiry with the Front Desk Officer, the applicant was guided to meet the ijārah Manager (IM) of the bank. The Chief Accountant placed two requests before IM; (i) Financing the purchase of vehicles in strict compliance of the principles of Shari' 'ah and (ii) Opening of Letter Of Credit (LC) worth Rs:100 million, so that import of the requisite raw material for vegetable cooking oil from Malaysia be facilitated. The ijārah manager explained as to how the corporate ijārah financing is different from consumer ijärah financing, in terms of detailed documentation, legal formalities, and associated risks. During the first interview with IM, the representative of the firm was asked to furnish accounts' statements of the firm so that a general impression about the financial health of the firm is taken and further processing is facilitated.

The documents revealed that hither to the firm had already availed two cars, one Alto Suzuki and one Honda Civic, on lease, and an application for two more cars was under process and had opened 3 LCs with different banks; one of which is just got mature and the other two were payable. As required by the bank, the firm submitted a balance sheet and income statement of the firm, audited by a chartered accountant. After evaluation of these documents by the Head Office of the bank, the applicant was asked to provide;

i. Request letter on firm's letter head;

ii. Financial Tax Returns;

iii. CNICs of the members of the board of directors; and

iv. Credit Resolution passed by the Board of Directors [BoD approved by the SECP]. Contrary 
to the assessment of Area Manager and Risk Management Unit, who observed mis-match between assets and liabilities of the firm, the IM made recommendations to the Head Office (HO) for further evaluation of the case.

\section{Qualitative Asessment}

To supplement the quantitative assessment of the firm as reported in the financial and other documents of the firm, the bank also made some qualitative assessment. The IM inquired from the branch manager about the validity, authenticity, and appropriateness of the accounts and other financial statements as provided by the client. The Area Manager endorsed the authenticity of these documents. The probe into the social reputation of the directors revealed them to be "trust worthy" as they also rendered their property to the United Nations office in Pakistan, and were having handsome monthly return, which also favored them to be recorded as "safe and sound".

\section{Documents Analysis}

To beef up the security of proposed financing, the IM asked the Registrar of the firm to submit report from Credit Information Bureau (CIB) of the State Bank of Pakistan, Form A, and H, and other Registration related documents of the firm. The Risk Management Unit (RMU) of the bank asked the client to submit sanction of every loan realized by the firm. The eCIB report revealed that the firm was indebted to the extent of Rs. 300 million in two separate loans. The volume of these loans was not in consonance to the overall assets and operations of the firm. The Credit Processor, therefore asked the IM to obtain complete information about all their loans. The client was also asked to submit financial return for several years as a single year return as provided by the client was not enough to assess the actual financial depth. In response to these observations, the client submitted financial reports for previous several years. Details of loans showed that the client had previously borrowed Rs 140 million from Bank Islami, and Rs 90 Million and Rs 40 Million from two other banks.

Sanction letters for each LC of the client pointed out that the limit of LC and its payment schedule were continuous and therefore it was difficult to provide a separate sanction letter for every LC under the time constraint. The plea was accepted and the client was asked to provide fully documented account of the loans limit, amount realized by the firm, loan paid and the balance left. As asked for by the bank, the firm provided form $\mathrm{H}$ and Registration Form but not Form A and Form 29. IM asked the client to submit these forms and sanction letters before the Resolution of Credit could be passed by the Board Of Directors of the firm. The RMU reduced all the information so far provided by the firm to a proforma so that the firm strengths and weaknesses could be ascertained at a glance.

The client submitted the remaining documents in about twenty days. IM, in consultation with the CIU, RMU and other relevant offices scanned these documents and submitted to Head Office for a favorable consideration. In about two weeks time the product manager, RMU and business manager confirmed the approval of financing and approval letter was duly sent to IM. Consequently, the IM conveyed approval to the client for further proceeding in the case. 


\section{Acquisition of Vehicles from Authorized Manufacturer/Distributor}

According to the specification of vehicles as required by the client the bank contacted HinoPak Peshawar to arrange for the desired vehicles. The total value of five trucks amounted to PKR 60 million - each had a cost of PKR 12 million. The customer was asked to make $30 \%$ down payment as agreed under the contract. The tenure of this ijārah financing was five years, a list of Payment Schedule annexed.

Prior to the delivery and possession of the vehicles, the bank concluded a standard detailed contract with the client in which all the perceived risks were covered, namely:

i. The supply risk, which occurs when the supplier delivered the vehicles which do not meet the specified quality and hence may result in rejection of the asset by the client.

ii. Price risks may occur in case of breach of contract by the client who may refuse to take possession of the asset. The lessor may suffer a loss equal to the difference between the amount receivable on account of total rentals and the selling price of such asset which may even be less than the purchased price.

iii. Settlement risk which may occur when the lessee is unable to service the lease rentals when it is due.

iv. Rate of return risk which occurs due to fluctuations in the market owing to higher return demanded by the investment account holders/investors as compared to return on lease.

v. Takâful which occurs when there is insufficient takâful to cover any mishap during the delivery and rental period.

vi. Legal risk accruing to the lessor when the asset purchased is not of desired quality, specification, is defective. When the lessee refuses to accept such defective goods, the lessor may incur cost on account of litigation, loss of claim, etc.

vii. Assets Impairment Risk may occur when the asset get destroyed due not to the misconduct of the lessee. In such a case the lessor has to provide an alternate asset or pay the balance rentals.

viii. Default risk is caused when bankruptcy occurs to the lessee. In such a situation the lessor may repossess the asset and sell it to any other party to recover its purchased price. Profit due on account of remaining rentals may however be lost.

\section{CONCLUDING REMARKS}

The costumer had a network within the country for oil distribution and the ijārah is utilized to expand its businesses. The customer approached Bank Islami for facilitating the company to meet its transportation needs in Shari' 'ah compliant way. Before entering into the ijārah 
contract, the firm operated only in local market, while after getting vehicles on from the Bank Islami, the company started distributing its products in Afghanistan. It was also planning to extend to Iran and central Asia. So, overall the transaction had a positive impact on the business. Further, the company avoided ribā based conventional banking and availed an Islamic mode of business.

\section{TEACHING NOTES}

\section{a) Learning Objectives:}

After discussing the case, it is aimed to be achieved the following in class objectives:

- To explain overall process of ijārah

- To explain the requirements of processing a corporate client Case.

- To explain the different issues that may arise during processing the ijārah Case

- To explain the repayment procedure for a period of 5 years

\section{b) Suitability of the Case}

This is case is suitable for:

- Undergraduate and graduate students taking courses in Islamic Banking and finance

- Trainees interested in understanding how Bank Islami facilitate corporate clients through ijārah

- Shari' 'ah scholar's interested in understanding in applied process of ijārah

- Credit Officers/Loan Officers/Retail Banking Officers working on the Seat newly inducted in Islamic Banking Industry

d) Assignment Questions

1) How many stakeholders are involved in the case of $i j a \overline{r a h}$ with corporate client? Identify and discuss their roles.

2) In your opinion what an alternative Islamic mode could the bank and the corporate client use to fulfill the same need of both bank and the client? Comparatively analyze ijārah and your proposed alternative Islamic mode.

3) What happens when a corporate client requests for early maturity of the facility availed?

4) Justify the Shari' 'ah compliance of Terminal Values on early termination?

6) Explain the repayment behavior of the customer for a period of 05 years?

e) Analysis

1) How many stakeholders are involved in the case of ijārah with corporate client? Identify and discuss their roles.

Hint: In this case of $i j a \overline{r a h}$ we see different roles of the Bank, customer:, SECP, SBP, Pak 
Hino Trucks, CA Firm, NADRA and currier companies, and avenues where bank make investment and parties looking for financing from the bank. However the theoretical model of ijärah only defines the role of bank, Party/customer and the supplier/distributor from whom the machinery will be bought through ijārah financing.

2) In your opinion what an alternative Islamic mode could the bank and investment account holder use to fulfill the same need of both bank and investment account holder? Comparatively analyze the mudārabah and your proposed alternative Islamic mode.

Hint: The bank could use mushärakah or the participatory mode for financing. According to many Shari' ${ }^{\prime}$ ah scholars, the originality of business is to be run jointly in form of shirkah, because customer feels more Shari' ah compliance in service, as in that case any type of risk would be distributed between bank and the corporate client. However banks avoid this form of services due to following reasons:

- Liberty of bank can be affected as the client becomes a partner in the machinery that is brought for running his business and utilize the transport as per his need after approval from the second partner i.e. Bank. Every time an approval of Bank and Client will be compulsory for using the machinery. While in ijärah, the Vehicle belong to one owner and the rent is paid only by the Lessee on monthly or quarterly basis.

- Liberty of the client can be affected as the Bank becomes a partner in the machinery that is brought for running the business of the client and thus a new partner is added in the business operations. While in ijärah, the Vehicle belong to one owner and the rent is paid only by the Lessee on monthly or quarterly basis.

- Financing Machinery on basis of mushārakah is less profitable for bank as compare to ijārah, because in ijärah bank is entitled to earn profit as per market rate; but in mushärakah, the bank can earn profit on its own share only.

- In case of $i j a \bar{r} r a h$, Losses will be borne by the owner only, while in mushärakah every partner is liable to bear loss according to their portion of capital.

- Financing a machinery on basis of mushārakah is complex as compared to ijārah

3) What happens when a corporate client request for early maturity of the facility availed?

Hint: If an ijärah facility was availed for five years and the customer request for early maturity after 03 years, then the profit that is earned by an Bank Islami will be considered as the total profit and recalculation of the whole facility be made as the customer is violating the agreement, so $2 \%$ of the terminal amount will be taken from him along with principal amount remaining only,. The rest of 02 years profit will not be taken from the client.

\section{4) Justify the Shari' ${ }^{\prime}$ ah compliance of Terminal Value on Pre mature Termination Charges?} Answer: in case of early payment the customer will be charged extra amount in account of price of leased asset, because the bank and client enter into a separate sale contract where 
parties are free to fix agreed price regardless its worth and quantity which may be differ from the quantity promised by bank at the beginning of the ijärah contract.

5) Calculate the repayment behavior of the corporate client for 05 years: 
TABLE 1

Calculation for repayment behavior of the corporate client for 05 years

\begin{tabular}{lc}
\hline \hline Date & March 21,2018 \\
\hline Customer & Sufi Oil \\
Account Number & $2765-1$ \\
Vehicle Description & Truck \\
Vehicle Price & $10,104,633 /-$ \\
Security Deposit & $3,000,000 /-$ \\
Profit Rate & $14 \%$
\end{tabular}

\begin{tabular}{llll}
\hline Installments & Due Date & Rentals & Terminal Value \\
\hline 1 & $3 / 21 / 2018$ & 185,468 & $10,790,017$ \\
2 & $4 / 21 / 2018$ & 185,468 & $10,681,981$ \\
3 & $5 / 21 / 2018$ & 185,468 & $10,572,763$ \\
4 & $6 / 21 / 2018$ & 185,468 & $10,462,351$ \\
5 & $7 / 21 / 2018$ & 185,468 & $10,350,731$ \\
6 & $8 / 21 / 2018$ & 185,468 & $10,237,890$ \\
7 & $9 / 21 / 2018$ & 185,468 & $10,123,813$ \\
8 & $10 / 21 / 2018$ & 185,468 & $10,008,487$ \\
9 & $11 / 21 / 2018$ & 185,468 & $9,891,897$ \\
10 & $12 / 21 / 2018$ & 185,468 & $9,774,030$ \\
11 & $1 / 21 / 2019$ & 185,468 & $9,654,870$ \\
12 & $2 / 21 / 2019$ & 185,468 & $9,759,405$ \\
13 & $3 / 21 / 2019$ & 185,468 & $9,640,157$ \\
14 & $4 / 21 / 2019$ & 185,468 & $9,519,602$ \\
15 & $5 / 21 / 2019$ & 185,468 & $9,397,725$ \\
16 & $6 / 21 / 2019$ & 185,468 & $9,274,511$ \\
17 & $7 / 21 / 2019$ & 185,468 & $9,149,945$ \\
18 & $8 / 21 / 2019$ & 185,468 & $9,024,011$ \\
19 & $9 / 21 / 2019$ & 185,468 & $8,896,695$ \\
20 & $10 / 21 / 2019$ & 185,468 & $8,767,980$ \\
21 & $11 / 21 / 2019$ & 185,468 & $8,637,852$ \\
22 & $12 / 21 / 2019$ & 185,468 & $8,506,293$ \\
23 & $1 / 21 / 2020$ & 185,468 & $8,373,288$ \\
24 & $2 / 21 / 2020$ & 185,468 & $8,441,321$ \\
25 & $3 / 21 / 2020$ & 185,468 & $8,307,661$ \\
26 & $4 / 21 / 2020$ & 185,468 & $8,172,531$ \\
27 & $5 / 21 / 2020$ & 185,468 & $8,035,915$ \\
28 & $6 / 21 / 2020$ & 185,468 & $7,897,796$ \\
29 & $7 / 21 / 2020$ & 185,468 & $7,758,157$ \\
30 & $8 / 21 / 2020$ & 185,468 & $7,616,982$ \\
31 & $9 / 21 / 2020$ & 185,468 & $7,474,252$ \\
\hline & & & \\
\hline
\end{tabular}


TABLE 1

Continue..

\begin{tabular}{lc}
\hline \hline Date & March 21,2018 \\
\hline Customer & Sufi Oil \\
Account Number & $2765-1$ \\
Vehicle Description & Truck \\
Vehicle Price & $10,104,633 /-$ \\
Security Deposit & $3,000,000 /-$ \\
Profit Rate & $14 \%$
\end{tabular}

\begin{tabular}{|c|c|c|c|}
\hline Installments & Due Date & Rentals & Terminal Value \\
\hline 32 & $10 / 21 / 2020$ & 185,468 & $7,329,950$ \\
\hline 33 & $11 / 21 / 2020$ & 185,468 & $7,184,059$ \\
\hline 34 & $12 / 21 / 2020$ & 185,468 & $7,036,560$ \\
\hline 35 & $1 / 21 / 2021$ & 185,468 & $6,887,436$ \\
\hline 36 & $2 / 21 / 2021$ & 185,468 & $6,918,918$ \\
\hline 37 & $3 / 21 / 2021$ & 185,468 & $6,768,545$ \\
\hline 38 & $4 / 21 / 2021$ & 185,468 & $6,616,514$ \\
\hline 39 & $5 / 21 / 2021$ & 185,468 & $6,462,807$ \\
\hline 40 & $6 / 21 / 2021$ & 185,468 & $6,307,405$ \\
\hline 41 & $7 / 21 / 2021$ & 185,468 & $6,150,288$ \\
\hline 42 & $8 / 21 / 2021$ & 185,468 & $5,991,438$ \\
\hline 43 & 9/21/2021 & 185,468 & $5,830,834$ \\
\hline 44 & $10 / 21 / 2021$ & 185,468 & $5,668,457$ \\
\hline 45 & $11 / 21 / 2021$ & 185,468 & $5,504,288$ \\
\hline 46 & $12 / 21 / 2021$ & 185,468 & $5,338,306$ \\
\hline 47 & $1 / 21 / 2022$ & 185,468 & $5,170,490$ \\
\hline 48 & $2 / 21 / 2022$ & 185,468 & $4,164,850$ \\
\hline 49 & $3 / 21 / 2022$ & 185,468 & $4,995,156$ \\
\hline 50 & $4 / 21 / 2022$ & 185,468 & $4,823,587$ \\
\hline 51 & $5 / 21 / 2022$ & 185,468 & $4,650,122$ \\
\hline 52 & $6 / 21 / 2022$ & 185,468 & $4,474,739$ \\
\hline 53 & $7 / 21 / 2022$ & 185,468 & $4,297,417$ \\
\hline 54 & $8 / 21 / 2022$ & 185,468 & $4,118,134$ \\
\hline 55 & $9 / 21 / 2022$ & 185,468 & $3,936,868$ \\
\hline 56 & $10 / 21 / 2022$ & 185,468 & $3,753,597$ \\
\hline 57 & $11 / 21 / 2022$ & 185,468 & $3,568,297$ \\
\hline 58 & $12 / 21 / 2022$ & 185,468 & $3,380,946$ \\
\hline 59 & $1 / 21 / 2023$ & 185,468 & $3,191,522$ \\
\hline 60 & $2 / 21 / 2023$ & 185,468 & $3,000,000$ \\
\hline Total & \multicolumn{3}{|c|}{$11,128,080$} \\
\hline
\end{tabular}




\section{REFERENCES AND READINGS}

Ayub, M. (2007). Understanding Islamic finance. New York, NY: John Wiley Sons

Mansoori, M. T. (2005). Islamic law of contracts and business transactions. Islamabad, Pakistan: Shariah Academy, International Islamic University.

SBP/IBD. (2008). Handbook of bank Islaming products $\mathcal{E}$ services. Karachi: State Bank of Pakistan.

Ullah, K., \& Al-Karaghouli, W. (2017). Understanding Islamic financial services. London, UK: KoganPage.

Usmani, I. A. (2015). Meezan banks guide to bank Islamiing. Karachi, Pakistan: Maktaba Maariful Quran.

Usmani, T. (2002). Introduction to Islamic finance. Amsterdam, Netherlands: Kluwer Law International. 